\title{
ANALISA HASIL BIOGAS MENGGUNAKAN ISI RUMEN SAPI SEBAGAI STARTER
}

\author{
Renilaili \\ Engineerring Departement, Bina Darma University, Palembang, Idnonesia \\ Email: renilaili@binadarma.ac.id
}

\begin{abstract}
Biogas is an environmentally friendly energy. The purpose of this experiment is to find out whether it is correct, by using a cumen rumen filler starter, the fermented biogas volume will become larger (more), compared to fermented cows fesses with water but not adding starter fluid of cow rumen contents. In this experiment 4 experiments were performed with the comparison (cows fesses: water: cow rumen fluid) are (1:2:0), (1:2:1), (1:2:2), and (1:2:3). The experiment lasts for 40 days, but within 10 days it has already produced biogas, this biogas will continue and there is reaction of asidogenesis and methanogenic reaction. From the observations made, the amount of biogas volume is also influenced by raw material ratio and fermentation time $(25,80 \mathrm{~cm} 3)$ with raw material ratio (1:2: 2) and fermentation time for 30 days. The result of this biogas is quite significant $(59.3 \%$,) more, here the starter function is quite dominant to increase the expected biogas production
\end{abstract}

Keywords: fesses, water, cow rumen fluid, anaerob, biogas.

\section{PENDAHULUAN}

Krisis energi menjadi permasalahan, buka saja di Indonesia, tetapi juga di Dunia.Pertumbuhan penduduk yang cepat dan maraknya industriindustri menyebabkan tingginya peningkatan permintaan energi. Di Indonesia tingginya permintaan energi ini menyebabkan harga minyak naik, sehingga meningkatkan biaya produksi barang dan jasa serta beban hidup masyarakat yang pada akhirnya memperlemah pertumbuhan ekonomi. [1]. Penggunaan bahan bakar di sektor industri, sektor transfortasi, dan disektor rumah tangga sangat besar, akibatnya kebutuhan energi sangat kurang. Kekurangan Energi dalam kehidupan manusia menjadi masalah yang cukup rumit dan mendasar, ini disebabkan karena setiap manusia membutuhkan energi bahan bakar , membutuhkan energi listrik, semua peralatan elektronik membutuhkan energi listrik dan kehidupan manusia sangat berkaitan erat dengan alat alat listrik, baik alat -alat rumah tangga maupun alat-alat lain ini yang kemudian, membuat orang beralih untuk mencari energi alternative, seperti energi surya, energi gelombang, energi mikro Hidro, energi biomassa dan sebagai nya yang merupakan energi terbarukan yang sangat diperlukan saat ini. Umumnya energi terbarukan sangat dibutuhkan saat ini ,karena energi terbarukan pada umumnya ramah lingkungan dan tidak akan habis-habis. Salah satu energi 


\section{Jurnal TEKNO}

(Civil Engineeering, Elektrical Engineeering and Industrial Engineeering)

Vol. 16, No : 1, April 2019 , p-ISSN:1907-5243, e-ISSN: 2655-8416

terbarukan yang ramah lingkungan adalah energi biomassa termasuklah energi biogas, energi biogas ini yang dapat menggantikan bahan bakar gas seperti LPG, dan LNG yang berasal dari energi Fosil. Energi biogas ini dapat dibuat dari bahan baku encenggondok [2], dapat juga dibuat dari sisa sayursayuran dan sisa buah-buahan [3], selain itu energi biogas dapat menggunakan kotoran hewan seperti Kerbau, sapi, kambing, kuda dan juga ayam (unggas lainnya). Dalam penelitian sebelumnya energi biogas yang berasal dari kotoran kotoran hewan bila di fermentasi akan jauh lebih cepat menghasilkan biogas jika dibandingkan fermentasi tanaman seperti enceng gondok dan sayuran, juga hasil biogas dari kotoran hewan lebih banyak hasilnya dan waktu fermentasi nya juga lebih singkat. Energi biogas yang didapat dari kotoran hewan seperti sapi dan kambing serta kuda saat ini banyak dilakukan orang terutama yang tinggal didaerah pedesaan. Energi biomassa yang bersumber dari kotoran ternak atau kotoran manusia serta sayur dan buah ini bisa dijadikan sebagai bahan baku pembuatan biogas [4].

Pemanfaatan kotoran sebagai substrat biogas juga dapat mengasilkan pupuk organik untuk tanaman [5].

Kotoran ternak merupakan pilihan yang tepat sebagai bahan baku dalam pembuatan biogas, karena didalam kotoran ternak telah mengandung bakteri metanogenik yang dapat menghasilkan gas methan [6] kotoran sapi, kuda kambing dan kerbau memiliki kandungan sellulose yang tinggi dan mudah diuraikan oleh bakteri, kotoran ternak mengandung nutrient utama untuk bahan pengisi biogas. Proses pembuatan biogas dipengaruhi oleh beberapa faktor, diantaranya suhu, $\mathrm{pH}$, substrat , pengadukan dan starter. Suhu optimum bakteri metanogenik yang bersifat mesofilik adalah $35^{\circ} \mathrm{C}$, bakteri metanogenik termofilik $50-60^{\circ} \mathrm{C}, \mathrm{pH}$ pembentukan gas methan berkisar antara $5,5-8,5$ dengan interval optimal adalah $7,0-8,0$

Untuk kebanyakan bakteri metanogen. Substrat yang menjadi bahan pembuatan biogas memiliki kandungan $\mathrm{C} / \mathrm{N}$ yang berbeda-beda. Bakteri yang yang mengkonsumsi habis unsur $\mathrm{C}$ tigapuluh kali lebih cepat dibandingkan unsur $\mathrm{N}$, sedangkan unsur karbon digunakan sebagai sumber energi dan unsur Nitrogen digunakan sebagai pembangun struktur sel bakteri [4].

Substrat yang terdapat dalam Digester lama kelamaan akan membentuk lapisan kerak yang akan mengeras. Lapisan kerak ini dapat mengambat produksi biogas, pencegahannya dapat dilakukan dengan pengadukan, dimana pengadukan termasuk kedalam faktor penentu produksi biogas [7]. Faktor yang juga menentukan dalam produksi biogas adalah starter yang dijadikan sebagai sumber mikroba untuk mengasilkan gas methan.

Tujuan penelitian ini adalah untuk mengetahui seberapa besar pengaruh penambahan volume biogas dengan cara memberikan tambahan isi rumen sebagai biostarter dalam memproduksi biogas tersebut, selanjudnya nya dilakukan uji nyala untuk memastikan apakah biogas yang dihasilkan mengandung gas methan lebih banyak atau tidak, specifikasi gas methan ditandai dengan nyala api yang berwarna biru. 


\section{Jurnal TEKNO}

(Civil Engineeering, Elektrical Engineeering and Industrial Engineeering)

Vol. 16, No : 1, April 2019 , p-ISSN:1907-5243, e-ISSN: 2655-8416

\section{METODE}

Metodologi yang digunakan dalam penelitian ini adalah dengan melakukan eksperimen dilaboratorium Teknik Industri, Bina darma Palembang selama 40 hari ( di bulan Januari sampai bulan Februari 2018) Dalam penelitian ini fesses sapi yang digunakan berasal dari fesses sapi dari tempat peternakan sapi yang berada didaerah Betung lebih kurang $60 \mathrm{KM}$ dari kota Palembang propinsi Sumatera Selatan, jadi bahan baku yang digunakan adalah fesses sapi dari fesses sapi ternak dengan bahan tambahan air dan menggunakan biostarter isi rumen sapi. Isi rumen sapi adalah isi dari perut besar sapi yang berupa rumput yang sudah bercampur dengan air liur sapi dan enzim-enzim dan bakteri bakteri yang berada dalam perut besar sapi ternak. Dalam eksperimen ini dilakukan 4 kali percobaan , 1 kali percobaan tanpa menggunakan starter dan 3 kali percobaan dengan menggunakan starter. Perbandingan antara fesses sapi : air : cairan isi rumen sapi adalah sebagai berikut, $(1: 2: 0),(1: 2: 1),(1: 2: 2)$ dan (1 $: 2 ; 3)$. Dari hasil penelitian sebelumnya yang dilakukan diketahui bahwa dalam waktu 10 hari eksperimen ini sudah menghasilkan biogas, dan biogas ini semakin lama akan semakin bertambah banyak sampai waktu 30 hari, tetapi setelah 30 hari biogas yang terbentuk akan semakin berkurang, pengecekan terhadap temperatur dan tekanan, juga $\mathrm{pH}$ dilakukan setiap 10 hari untuk melihat apakah sudah sesuai dengan pertambahan biogas yang dihasilkan..

\subsection{Cairan Isi Rumen sapi.}

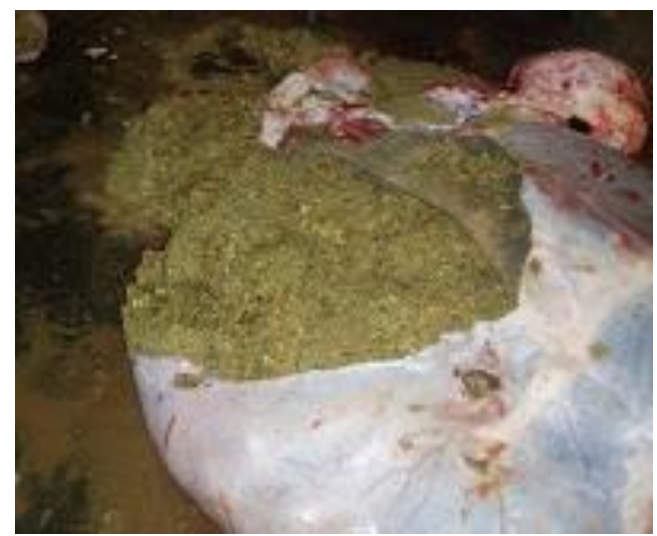

Gambar 1. Cairan isi rumen sapi

Cairan Isi rumen sapi, merupakan salah satu limbah dari rumah potong hewan yang belum dimanfaatkan secara optimal, bahkan ada yang dibuang begitu saja sehingga menimbulkan pencemaran lingkungan. Limbah isi rumen sebenarnya sangat potensial bila dimanfaatkan sebagai bahan pakan atau sumber vitamin $\mathrm{B}$ untuk hewan sejenis. 


\section{Jurnal TEKNO}

(Civil Engineeering, Elektrical Engineeering and Industrial Engineeering)

Vol. 16, No : 1, April 2019 , p-ISSN:1907-5243, e-ISSN: 2655-8416

Kuantitas dan kualitas isi rumen dapat dipengaruhi oleh jenis ternak, bobot badan ternak serta mikroba yang terdapat dalam saluran pencernaan ternak itu sendiri, disamping itu kualitas isi rumen juga tergantung dari makanan ternak yang dikonsumsinya.

Didalam rumen ternak ruminansia seperti sapi,kambing, kerbau dan domba terdapat populasi mikroba yang cukup banyak jumlahnya.

Cairan rumen mengandung bakteri dan protozoa ,konsentrasi bakteri sekitar $10{ }^{9}$ setiap $1 \mathrm{cc}$ isi rumen, sedangkan protozoa sekitar $10^{6}$ setiap $1 \mathrm{cc}$ isi rumen. Isi rumen sapi adalah cairan yang berada dalam perut besar sapi , dimana cairan tersebut bercampur rumput bahan makanan sapi ,yang telah larut sebagian dan bercampur lendir atau enzim lipase, terdapat didalam perut besar sapi, apabila sapi makan rumput, maka cairan rumen ini akan ikut sama sama berada dalam perut besar sapi tersebut, cairan rumen ini terdiri dari asam, bakteri atau mikroba yang terdiri dari protozoa, volatile fatty acid serta jamur, apabila sapi beristirahat maka sapi akan kembali mengeluarkan cairan rumen beserta rumput yang telah bercampur untuk dikembalikan lagi kemulut sapi (proses ini disebut proses memamah biak) dan kemudian akan dikunya kembali agar lebih halus , kemudian baru ditelan. Kandungan zat makanan yang terdapat dalam cairan rumen meliputi, air $(10,92 \%)$, protein $(8,86 \%)$, lemak $(2,60 \%)$, serat $\operatorname{kasar}(28,78 \%)$, dan fospor $(0,55 \%)$ serta sisanya berupa kalsium dan lain lain.Jumlah mikroba yang terdapat dalam cairan rumen bervariasi meliputi mikroba proteolitik $\left(2,5 \times 10^{9} \mathrm{sel} / \mathrm{gram}\right)$, mikroba sellulolitik $\left(8,1 \times 10^{4}\right.$

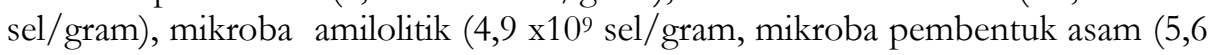
$\left.\mathrm{x} 10^{9} \mathrm{sel} / \mathrm{gram}\right), \quad$ mikroba lipolitik berkisar antara $(1,7 \mathrm{x} 103$ sel/gram).Mikroorganisme tersebut mencernai pati, gula,lemak, protein dan Nitrogen, bukan protein untuk membentuk mikrobial dan vitamin.

\subsection{Bahan dan alat yang digunakan}

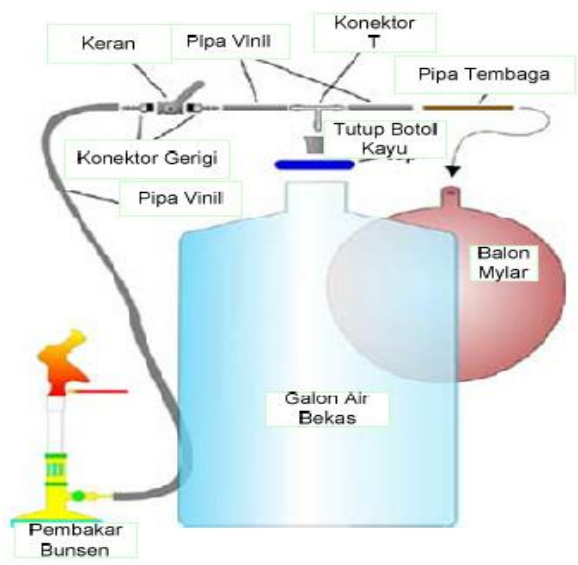

Gambar 2. alat pembuatan biogas 


\section{Jurnal TEKNO}

(Civil Engineeering, Elektrical Engineeering and Industrial Engineeering)

Vol. 16, No : 1, April 2019 , p-ISSN:1907-5243, e-ISSN: 2655-8416

Bahan terdiri dari Fesses sapi, Air , dan isi rumen sapi sedangkan alat yang digunakan berupa derijen plastik $30 \mathrm{~kg}$, Thermometer, $\mathrm{pH}$ meter dan selang plastik untuk mengalirkan gas, penampung biogas digunakan balon biogas, sedangkan untuk mengukur tekanan bisa digunakan pressure meter, atau kertas $\mathrm{pH}$, serta pengaduk.

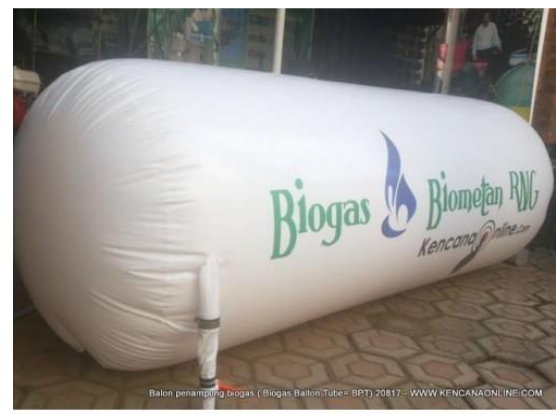

Gambar 3. Alat penampung Biogas

Dalam eksperimen ini dibuat perbandingan antara (Fesses : air : isi rumen sapi ) dengan perbandingan ( $1: 2: 1),(1: 2: 2)$ dan $(1: 2: 3)$ tetapi sebelum dilakukan fermentasi, ke 3 bahan tersebut harus diaduk terlebih dahulu supaya campuran menjadi lebih homogen. Fermentasi dilakukan selama 40 hari, pengamatan terhadap $\mathrm{pH}$ dan temperatur gas diamati dalam setiap 10 hari, tekanan yang diamati adalah tekanan didalam reaktor biogas.

Dari percobaan ini dapat diketahui bahwa biogas sudah mulai terjadi pada hari ke 10 , ini dapat diketahui dari terjadinya perubahan tekanan dari kondisi awal, bearti pada hari tersebut sudah mulai terjadi reaksi metanogenik, yang disebabkan karena bakteri-bakteri baik dalam fesses maupun dalam cairan rumen yang sangat banyak mengandung bakteri. Penelitian Yeni dkk (2012) mendapatkan hasil bahwa penambahan isi cairan rumen sapi mampu meningkatkan volume biogas yang terbentuk sampai $50 \%$, dibandingkan dengan yang tidak menambahkan isi rumen .Penambahan cairan isi rumen juga bisa mempersingkat waktu pembentukan biogas, hal ini dikarenakan cairan rumen sapi sangat banyak mengandung bakteri yang dapat membantu proses reaksi metanogenik. Cairan rumen sapi dari limbah rumah potong hewan dapat dimanfaatkan sebagai biostarter untuk mempercepat proses fermentasi kotoran untuk menghasilkan dan meningkatkan produksi gas methan dalam biogas [3], jenis fesses juga mempengaruhi banyaknya pembentukan biogas. 


\section{Jurnal TEKNO}

(Civil Engineeering, Elektrical Engineeering and Industrial Engineeering)

Vol. 16, No : 1, April 2019 , p-ISSN:1907-5243, e-ISSN: 2655-8416

\section{HASIL DAN PEMBAHASAN}

Sebagai pembanding, dalam penelitian ini dicoba melakukan eksperimen untuk fesses sapi dengan perbandingan (fesses sapi : air : isi rumen sapi ) adalah ( $1: 2: 0)$, Perlakuan sama sebelum masuk ke digester harus diaduk terlebih dahulu agar fermentasi berjalan dengan baik. Fermentasi dilakukan selama 1 bulan penuh dalam kondisi anaerob. Selanjudnya eksperimen dlakukan lagi dengan cara yang sama tapi dengan penambahan isi rumen. Dalam digester diusahakan selalu kedap udara sehingga fermentasi berjalan dengan lebih sempurna, sebelum dilakukan fermentasi campuran dari (Fesses sapi, air dan Cairan rumen ) dengan perbandingan tertentu yaitu $(1: 2: 0),(1: 2: 1),(1: 2: 2)$ dan $(1: 2: 3)$ dilakukan pengadukan terlebih dahulu agar campuran lebih homogen, setelah mencapai homogen baru dimasukkan kedalam digester, dan difermentasi, selama 40 hari penuh dalam kondisi anaerob.

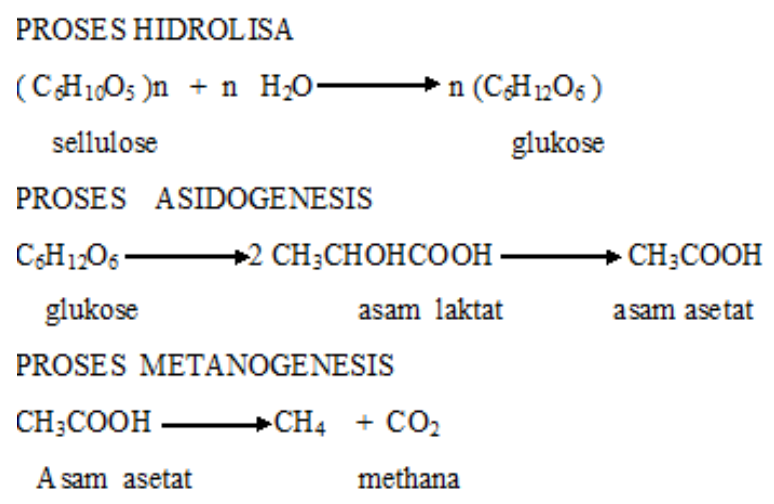

Tekanan gas dalam penampungan gas, menunjukkan semakin banyaknya biogas yang terbentuk sebagai hasil fermentasi dengan melihat perbandingan dalam campuran. Dari hasil pengamatan dapat diketahui bahwa semakin banyak cairan rumen yang dipakai maka akan semakin banyak biogas yang terbentuk dari hasil fermentasi.

Dari hasil pengamatan terhadap perubahan temperatur, perubahan terhadap $\mathrm{pH}$ serta perubahan terhadap volume biogas yang dihasilkan selama 10 hari, 20 hari ,30 hari sampai 40 hari.

Maka didapatlah hasil pengamatan seperti dalam tabel berikut ini. 


\section{Jurnal TEKNO}

(Civil Engineeering, Elektrical Engineeering and Industrial Engineeering)

Vol. 16, No : 1, April 2019 , p-ISSN:1907-5243, e-ISSN: 2655-8416

Tabel 3.1 perbandingan bahan terhadap suhu optimum serta $\mathrm{pH}$ dengan Tambahan isi rumen

\begin{tabular}{ccc}
\hline $\begin{array}{c}\text { Perbandingan } \\
\text { Feses: Air : tambahan } \\
\text { isi rumen }\end{array}$ & Temperature $\left({ }^{\circ} \mathrm{C}\right)$ & $\mathrm{pH}$ \\
\hline $1: 2: 0$ & $27-30$ & $6,8-7,5$ \\
$1: 2: 1$ & $28-32$ & $6,8-7,5$ \\
$1: 2: 2$ & $28-35$ & $6,8-7,7$ \\
$1: 2: 3$ & $28-37$ & $6,8-8,0$
\end{tabular}

Sumber: pengamatan di lab 2018

Dalam tabel diatas terlihat bahwa pengamatan terhadap suhu masih dalam kondisi normal Karena masih dalam range $28^{\circ} \mathrm{C}-35^{\circ} \mathrm{C}$., sedangkan $\mathrm{pH}$ juga masih dalam range 6,5 - 8,1. Dalam eksperimen ini terlihat bahwa waktu fermentasi cukup berpengaruh terhadap volume hasil biogas, makin lama waktu fermentasi makin besar volume hasil biogas.

Tabel 3.2 Perbandingan bahan baku terhadap Hasil Volume biogas yang dihasilkan.

\begin{tabular}{ccccc}
\hline $\begin{array}{c}\text { Perbandingan } \\
\text { Feses: Air: } \\
\text { tambahan isi } \\
\text { rumen }\end{array}$ & \multicolumn{3}{c}{ Volume Hasil Biogas Dalam Kurun Waktu Tertentu } \\
\cline { 2 - 5 }$\left(\mathrm{cm}^{2}\right)$ \\
\hline $1: 2: 0$ & 10,22 & 11,38 & 12,56 & 40 hari \\
$1: 2: 1$ & 12,67 & 15,90 & 16,20 & 12,7 \\
$1: 2: 2$ & 13,70 & 14,87 & 25,80 & 16,0 \\
$1: 2: 3$ & 14,60 & 15,90 & 16,90 & 12,90 \\
\hline
\end{tabular}

\section{Sumber : Lab Teknik Industri, 2018}

Penambahan cairan rumen sapi terhadap produksi biogas pada fesses sapi ternak memang banyak berpengaruh dalam meningkatkan produksi biogas. Pada Fermentasi yang menggunakan fesses sapi ,semakin lama waktu fermentasi, maka semakin banyak biogas yang dihasilkan. Dari penelitian yang dilakukan menunjukkan bahwa ada intraksi atau hubungan yang positif antara waktu fermentasi dengan penambahan isi rumen sebagai starter terhadap hasil produksi biogas.Dari tabel diatas terlihat bahwa perbandingan 


\section{Jurnal TEKNO}

(Civil Engineeering, Elektrical Engineeering and Industrial Engineeering)

Vol. 16, No : 1, April 2019 , p-ISSN:1907-5243, e-ISSN: 2655-8416

hasil yang significan terlihat pada ( $1: 2: 2$ ) pada fermentasi 30 hari yaitu sebesar $25,8 \mathrm{~cm}^{3}$ lebih besar dibandingkan hasil yang lain.

\subsection{Pengamatan Uji Nyala}

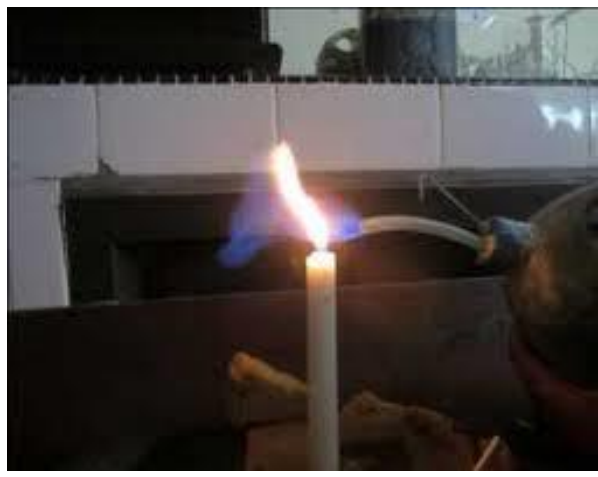

Gambar 4. Uji nyala

Pengujian terhadap nyala biogas bisa dilakukan dengan membandingkan nyala lilin dengan nyala biogas

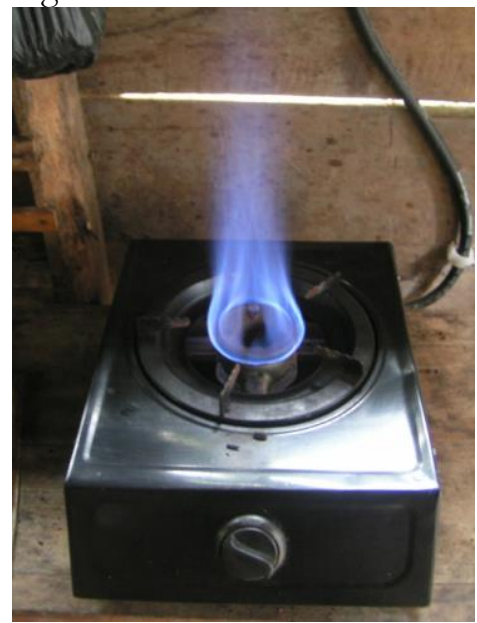

Gambar 5. Dengan Kompor biogas

Pada gambar diatas jelas sekali terlihat bahwa nyala yang ditimbulkan oleh kompor biogas berwarna biru terang, hal ini sama dengan nyala LPG yang banyakmengadung molekul gas methane.

Pada pengamatan uji nyala, gas yang sumber api untuk memastikan apakah gas banyak mengandung methane atau tidak. Uji positif ditandai dengan nyala api warna biru. Tekanan gas dalam Digester menunjukkan semakin banyaknya biogas yang terbentuk sebagai hasil fermentasi dengan melihat perbandingan dalam campuran. Dari hasil pengamatan dapat diketahui 


\section{Jurnal TEKNO}

(Civil Engineeering, Elektrical Engineeering and Industrial Engineeering)

Vol. 16, No : 1, April 2019 , p-ISSN:1907-5243, e-ISSN: 2655-8416

bahwa semakin banyak cairan rumen yang dipakai maka akan semakin banyak biogas yang terbentuk dari hasil fermentasi.

\section{KESIMPULAN}

Dari hasil pembahasan diatas maka dapatlah di simpulkan sbb:

1. Kualitas Biogas akan lebih baik apabila kadar methan $\left(\mathrm{CH}_{4}\right)$ lebih tinggi.

2. Makin besar volume cairan isi rumen yang dipakai sebagai starter, serta makin lama waktu fermentasi maka gas methan yang terbentuk semakin banyak, hal ini berarti nilai kalor biogas akan semakin tinggi.

3. .Dari hasil eksperimen didapat perbandingan hasil biogas tanpa menggunakan isi rumen dengan yang menggunakan isi rumen terlihat

4. bahwa pemakaian isi rumen sebagai starter berpengaruh cukup significan terhadap hasil biogas.

\section{Saran}

Perlu dilakukan penelitian lebih lanjut dan lebih detail lagi masalah ratio subtrat yang dipakai, karena hasil biogas bukan saja tergantung dari ratio substrat tetapi banyak faktor seperti jenis starter, $\mathrm{pH}$, temperatur, pengadukan

\section{DAFTAR PUSTAKA}

[1] Widodo,T.,A Asari 2006, Rekayasa dan pengujian reaktor biogas skala kelompok tani ternak Jurnal Enjinering Pertanian Vol. IV No.1.Hal 4.

[2] Reni, 2014. Enceng gondok sebagai Biogas yang ramah lingkungan Jurnal Tekno, Vol 11. No.1, April 2014

[3] Susilowati, E 2009. Uji Pemanfaatan cairan rumen sapi untuk meningkatkan kecepatan produksi biogas dan konsentrasi gas methan dalam biogas.Tesis Universitas Gajah Mada.

[4] Bayu seno, A.,P .2009.Penerapan dan Pengujian model teknologi anaerob digester untuk pengolahan sampah buah-buahan dari pasar tradisional.

Rotasi, vol.11 Hal .5

[5] Putro,S.2007. Penerapan Instalasi sederhana Pengolahan kotoran sapi , menjadi energi biogas didesa sugihan kecamatan bendosari di kabupaten Sukoharjo.Warta, vol10.No.02.

[6] Reni, 2015 Hasil biogas dengan menggunakan Reaktor Fiberglass dari 3 jenis sapi, Jurnal Tekno, Vol 12. No.2, AOktober 2015.

[7] Siregar,R.T .2004,Uji frekuensi pengadukan dan konsentrasi kotoran kuda terhadap produksi biogas. Skripsi Universitas Sumatera Utara. 